\title{
RADIOACTIVE WASTE DISPOSAL SITE SELECTION ${ }^{1,2}$
}

\author{
Boyko Vachev \\ Astrophysical Objects and Environment Laboratory \\ Institute for Nuclear Research and Nuclear Energy, Bulgarian Academy of Sciences \\ 72, Tzarigradsko shaussee blvd., 1784 Sofia - Bulgaria \\ vachev@inrne.bas.bg
}

Keywords: radioactive waste management, multicriteria choice.

Summary: The present paper treats the application of the approach and methods of system analysis and Analytical Hierarchical Process (AHP) for the solution of a typical problem of the decision-making theory - the site selection problem. The specific features of site selection for highly radioactive waste repository is the high degree of uncertainty, as well as the high responsibility of the choice itself"responsibility for the future generations". The hierarchical structuring, the multi-model approach and the adequacy analysis overcome the uncertainty. A procedure has been developed including a set of AHP models - relative and ranking ones, applied to a different degree of detail and to different elements of the decision-making process. The analysis is performed and a choice is realized in a set of 30 potential sites according to 28 criteria distributed in 5 groups, the sites being evaluated using the criteria and 5 typical non-linear scales of preference.

\section{Introduction}

The problem of site selection for the construction of a permanent repository for highly radioactive waste disposal is one of the basic elements of the system for radioactive waste management. This is a typical decision-making problem - the available data are given namely a set of variants (sites), a set of criteria and experts, as well as the goal - ranking and selection of prospective sites. The problem contains some uncertainty that could be regarded as objective and subjective one (Vachev, 1987). For example, while most of the criteria are characterized by subjective uncertainty, the processes of the climatic, tectonic and seismotectonic development are described by objective uncertainty.

For this reason, the definition and diminution of uncertainty is the main concern when solving similar types of problems. The following approach and tools are applied for their solution:

- $\quad$ hierarchical structuring (special type of structure of the sets of criteria and sites);

- adequacy analysis (including the sensitivity analysis, adequate system for obtaining and assessing the statistical and experimental data and expert considerations, scenario analysis, etc.);

- multi-model approach (use of different types of decision-making models and comparative analysis of their results).

A number of approaches and methods exist for the solution of similar decision-making problems, one of the most suitable and efficient being the Analytical Hierarchical Process (AHP), developed in the end of the eighties by Prof. Thomas L. Saaty (Saaty, 1990). This approach has already been used for the

\footnotetext{
${ }^{1}$ The paper presents the work performed and financially supported by Project 102/98 "Investigations on Prospective Sites for the Construction of a National Radioactive Waste Repository" of the Fund for Structural and Technological Policy of the Bulgarian Ministry of Education and Science, completed in the end of 2000.

${ }^{2}$ The author would like to acknowledge his gratitude for the more than 10-year long fruitful co-operation with the colleagues from the Geological Institute of BAS, and especially with Prof. Dimcho Evstatiev, Prof. Dimitar Kozhoukharov and Corresponding Member of BAS Prof. Ilia Brouchev.
} 
development of the Concept of the Bulgarian Academy of Sciences (BAS) for a National Radioactive Waste Repository (Vachev et al., 1983; Vachev, 1987; Vachev and Evstatiev, 1994) and has been approved by the PHARE Project (Radioactive Waste Management in Bulgaria, 1997) and in (Kozhoukharov et al., 2000).

Figure 1. Block - scheme of common procedure for ranking of potential sites for high radioactive waste disposal

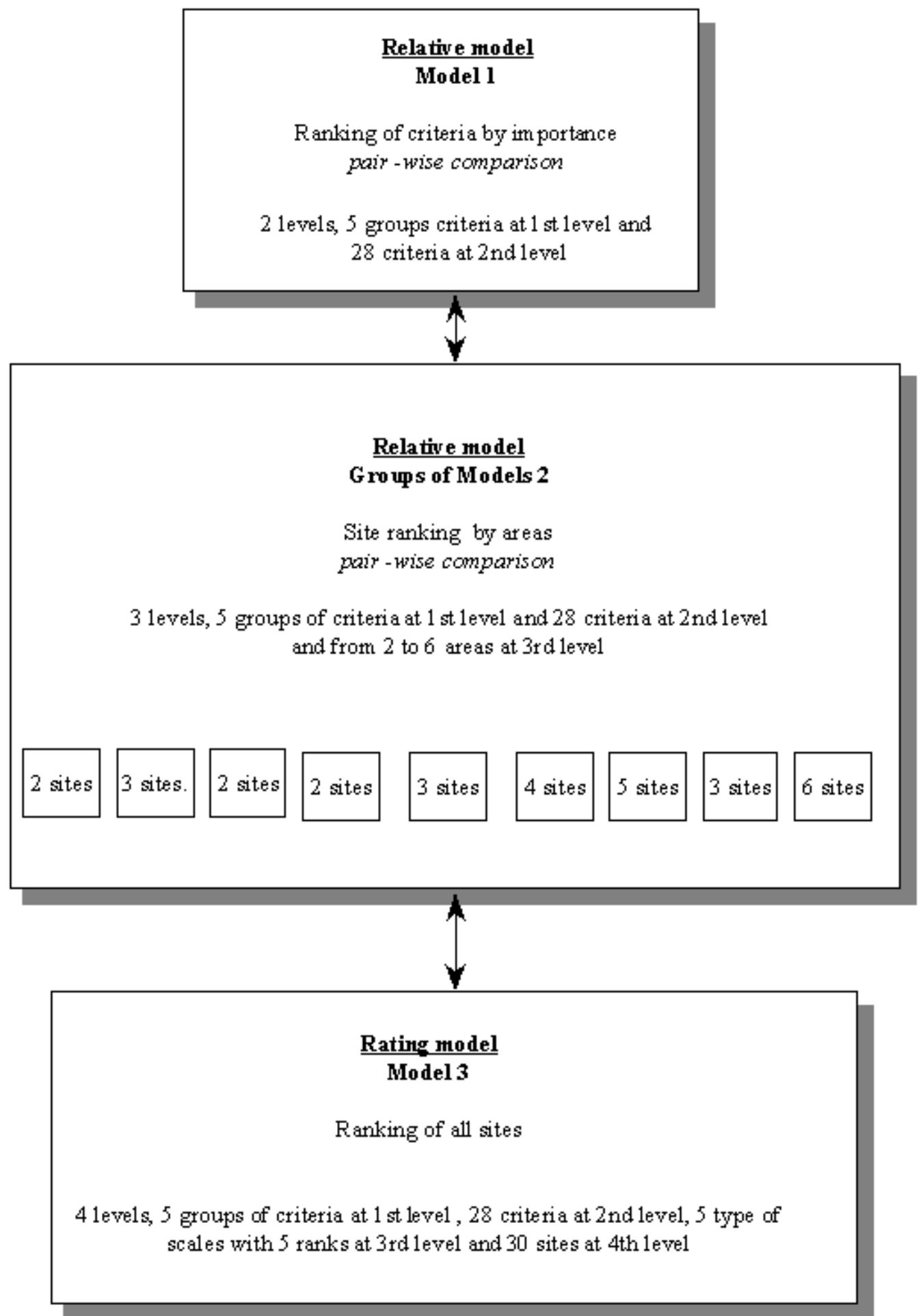




\section{Model for Site System Analysis and Assessment}

\subsection{Structure and Characteristics of the Model}

The model for system analysis and assessment of sites is developed on the basis of the assumed hierarchical structure of the criteria for assessment and selection, the set of sites, the site selection process (the stage of regional investigations) and the AHP approach and the Expert Choice 8.0, 9.5 software product.

The model includes 5 levels:

- level 0 contains the top - the goal of the model - "Analysis, assessment and selection of sites for the construction of a National Repository for Radioactive Waste Disposal"

- level 1 contains 5 groups of criteria

- $\underline{\text { level } 2}$ contains 28 independent criteria

- $\underline{\text { level } 3}$ consists of the assessment scales for each criterion and their ratings

- $\quad$ level 4 includes a set for selection, consisting of 30 sites, classified in 9 areas

Both relative and rating models are used (see Figure 1), the use of the latter being imposed by the great number of variants for selection and not by the usual practice of absolute assessment of site variants according to the corresponding scales.

\subsection{Procedure for Analysis, Assessment and Selection of Sites at the Current Stage of the Selection Process}

The procedure includes the following main stages (the realised main stages are shown schematically in Figure 1):

E1. Development of a rating model (based on absolute site comparison):

E1.1. Measurement of importance by means of binary comparisons of:

a) the groups of criteria

b) the criteria in each group

E1.2. Creation of absolute scales with rating of intensities;

E1.3. Assessment of the sites according to each criterion (in a rating table), using the created absolute scales.

E2. Ranking and analysis of site ranking.

E3. Development (preceding the rating model) of a group of relative models for arranging the sites within the framework of each area, using comparison in pairs.

E4. Development of a relative model (for the first group of most prospective ranked sites).

E5. Sensitivity analysis.

E6. Comparative analysis

E7. Adequacy analysis

E8. Analysis of results.

\section{Ranking of the Potential Sites}

\subsection{Assessment of the Importance of the Groups of Criteria and of the Criteria - Model 1}

The mutual importance of the groups of criteria and of the single criteria in each group is evaluated using relative comparisons in pairs (binary assessment of preference) (see Figure 1) among the set of criteria (see Table .1).

The assessments are made using a verbal scale of preference (with degrees respectively 1,3,5,7,9 and their intermediate 2,4,6,8). Questionnaires generated by the Expert Choice software product have been used. 
Table 1. Site selection criteria set structure

\begin{tabular}{|c|c|}
\hline $\mathbf{E}$ & Host formation geological conditions safety \\
\hline E1 & Geological structure \\
\hline E2 & Litological type and mineralogical content \\
\hline E3 & Geo - chemical properties \\
\hline E4 & Physical properties \\
\hline E5 & Hydro - geological conditions \\
\hline $\mathbf{F}$ & Environment stability \\
\hline F1 & Climate development \\
\hline F2 & Tectonic development \\
\hline F3 & Neo - tectonic activity \\
\hline F4 & Regional stress field \\
\hline F5 & Volcanism and diapirism \\
\hline F6 & Floods hazard \\
\hline G & Engineering reliability \\
\hline G1 & Mining and geo technical conditions \\
\hline G2 & Seismic conditions \\
\hline G3 & Topographical conditions \\
\hline G4 & Exogeodynamic processes \\
\hline G5 & Drilling and mining \\
\hline G6 & Hazard of technogenic origin \\
\hline G7 & Construction and operating expenses \\
\hline H & Environmental impact \\
\hline $\mathrm{H} 1$ & Water and mineral resources \\
\hline $\mathrm{H} 2$ & Land use \\
\hline H3 & Radioactive wastes transportation \\
\hline $\mathrm{H} 4$ & National heritage \\
\hline H5 & Flora and fauna impact \\
\hline H6 & Population radiological impact \\
\hline I & Socio-economic permissibility and acceptability \\
\hline I1 & Population and settlement density \\
\hline $\mathrm{I} 2$ & Nuclear experience and compensations for citizens \\
\hline $\mathrm{I} 3$ & Communication infrastructure \\
\hline I4 & Adverse effect on other economical activities \\
\hline I5 & Proximity to country borders \\
\hline
\end{tabular}

The assessments of this model and of the rest models are made by a group of leading experts. ${ }^{3}$ The procedure for lowering the inconsistency index values has been applied. A distributive mode is used for the synthesis. The sorted according to their importance results are shown in Figure 2.

The more significant conclusions from assessing the importance of the groups of criteria and of the single criteria for each group are as follows:

- the highest coefficient of importance belongs to the group of criteria H "Environmental impact", that corresponds to the international practice;

- the next important group of criteria is E "Host formation geological conditions safety". The influence of the natural barriers against radionuclide migration is taken under consideration in this way;

- the most important of the single criteria is the criterion H6 "Population radiological impact".

${ }^{3}$ Group of experts from the Geological Institute of the Bulgarian Academy of Sciences: Dimitar Kozhoukharov, Dimcho Evstatiev, Doncho Karastanev and Krastyo Todorov 


\subsection{Assessment and Ranking of Sites for each Area separately by Comparison in Pairs - Group of Models 2}

Model 1 has been applied for ranking of the prospective sites for each area separately (see Figure 1).

The main idea of using a relative model for the single sites is the maximal involving of expert competence and knowledge for a given territory. The obtained result is much more precise than that obtained using the site comparison according to absolute scales because of the substantial uncertainty of some of the criteria. The only disadvantage of this approach is that local optima are obtained for each single area, so excluding the possibility of regarding them as most prospective sites. The results for this group of models are used later during the third stage of analysis and assessment to precise the obtained ranking of the rating model, applied for all the 30 sites simultaneously.

The results of the 9 models run (consisting of 3 levels and containing: 5 groups of criteria, 28 criteria grouped in sets of 5,6,6,6,5 and comparing respectively 2, 3, 2, 2, 3, 4, 5, 3, 6 sites) are presented in Table 2.

Table 2. Sites ranking for every area

\begin{tabular}{|c|c|c|c|c|c|c|c|}
\hline & & & & & $\%$ TOT & $\% \mathrm{MAX}$ & \\
\hline $\mathrm{N}$ & Site N & Site N & Area name & Site name & Rank 1 & Rank 2 & $1 \mathrm{st}$ \\
\hline 1 & 1 & $010 \mathrm{~S}$ & Severozapadna Bulgaria & Deleina & 0,562 & $100 \%$ & \multirow[t]{2}{*}{$010 \mathrm{~S}$} \\
\hline 2 & 4 & $040 \mathrm{~S}$ & Severozapadna Bulgaria & Dalgodeltzi & 0,438 & $78 \%$ & \\
\hline 3 & 8 & $080 \mathrm{~S}$ & Dolnocredni tereni & Sumer & 0,413 & $100 \%$ & \multirow[t]{3}{*}{ 080S } \\
\hline 4 & 9 & $090 \mathrm{~S}$ & Dolnocredni tereni & Varbitza & 0,305 & $74 \%$ & \\
\hline 5 & 15 & $150 \mathrm{~S}$ & Dolnocredni tereni & Zlatar & 0,282 & $68 \%$ & \\
\hline 6 & 13 & $130 \mathrm{~S}$ & Belene & Oresh & 0,563 & $100 \%$ & \multirow[t]{2}{*}{$130 \mathrm{~S}$} \\
\hline 7 & 12 & $120 \mathrm{~S}$ & Belene & AEC-Belene & 0,437 & $78 \%$ & \\
\hline 8 & 23 & $230 \mathrm{~S}$ & Avren & Oreta & 0,637 & $100 \%$ & \multirow[t]{2}{*}{$230 \mathrm{~S}$} \\
\hline 9 & 24 & $240 \mathrm{~S}$ & \begin{tabular}{|l|} 
Avren \\
\end{tabular} & Devisilovo & 0,363 & $57 \%$ & \\
\hline 10 & 25 & $250 \mathrm{~S}$ & Jalti chal & Vangelova chuka & 0,419 & $100 \%$ & \multirow[t]{3}{*}{$250 \mathrm{~S}$} \\
\hline 11 & 27 & $270 \mathrm{~S}$ & Jalti chal & Kerezliiska reka & 0,326 & $78 \%$ & \\
\hline 12 & 26 & $260 \mathrm{~S}$ & Jalti chal & Kurbanlaka & 0,255 & $61 \%$ & \\
\hline 14 & 29 & $290 \mathrm{~S}$ & Belorechka struktura & Chomakovia kladenec & 0,295 & $100 \%$ & \multirow[t]{4}{*}{$290 \mathrm{~S}$} \\
\hline 13 & 28 & $280 \mathrm{~S}$ & Belorechka struktura & Sveta Elena & 0,241 & $82 \%$ & \\
\hline 15 & 31 & $310 \mathrm{~S}$ & Belorechka struktura & Pojarite & 0,236 & $80 \%$ & \\
\hline 16 & 30 & $300 \mathrm{~S}$ & Belorechka struktura & Kodja guile & 0,228 & $77 \%$ & \\
\hline 17 & 35 & $350 \mathrm{~S}$ & Harmanliiski blok & Orlina & 0,229 & $100 \%$ & \multirow{5}{*}{$\begin{array}{l}350 \mathrm{~S} \\
35 \mathrm{AS}\end{array}$} \\
\hline 18 & $35 \mathrm{a}$ & $35 \mathrm{AS}$ & Harmanliiski blok & Kumtarla & 0,229 & $100 \%$ & \\
\hline 19 & 34 & $340 \mathrm{~S}$ & Harmanliiski blok & Ratiovitza & 0,197 & $86 \%$ & \\
\hline 20 & 33 & $330 \mathrm{~S}$ & Harmanliiski blok & Huhla & 0,194 & $85 \%$ & \\
\hline 21 & 32 & $320 \mathrm{~S}$ & Харманлийски блок & Giklidja & 0,151 & $66 \%$ & \\
\hline 22 & 36 & $360 \mathrm{~S}$ & Iugoiztochen Sakar & Aiazmoto & 0,455 & $100 \%$ & \multirow[t]{3}{*}{$360 \mathrm{~S}$} \\
\hline 23 & 37 & $370 \mathrm{~S}$ & Iugoiztochen Sakar & Bialata cheshma & 0,298 & $65 \%$ & \\
\hline 24 & 38 & $380 \mathrm{~S}$ & Iugoiztochen Sakar & Kachulka & 0,247 & $54 \%$ & \\
\hline 25 & $39 \mathrm{a}$ & 39AS & Sakar & Garvanski kamak & 0,224 & $100 \%$ & \multirow[t]{6}{*}{ 39AS } \\
\hline 26 & 39 & $390 \mathrm{~S}$ & Sakar & Stanchovo pladniste & 0,208 & $93 \%$ & \\
\hline 27 & 40 & $400 \mathrm{~S}$ & Sakar & Sakartzi & 0,191 & $85 \%$ & \\
\hline 28 & 41 & $410 \mathrm{~S}$ & Sakar & Kushlovetz & 0,149 & $67 \%$ & \\
\hline 29 & 42 & $420 \mathrm{~S}$ & Sakar & Iukpazar & 0,117 & $52 \%$ & \\
\hline 30 & $42 \mathrm{a}$ & 42AS & Sakar & Gospodinovi dabichki & 0,111 & $50 \%$ & \\
\hline
\end{tabular}




\subsection{Assessment and Ranking in the Set of Sites Using a Rating Model - Model 3}

The relative model cannot be applied when there is a great number of variants (as in the present case - 30) because of the great number of comparisons (Figure 1). A rating model is constructed in similar cases (Figure 4), a scale with several levels of different degree of preference being formed for each criterion. The scale is non-linear as a rule.

Taking under consideration the use of quality assessments for some of the criteria, as well as the great differences in their importance (see Figure 2), a decision has been made for the application of several typical scales with non-linear relationship between the levels and degrees of preference. This relationship is represented by a monotonous concave or convex curve depending on the criteria importance - the more important criteria are characterized by a convex curve and the less important - by a concave one (like fuzzy sets membership function). The scales reflect verbally the adjective "favorable" (unfavorable - 1, low favorable - 2, moderate favorable - 3, high favorable - 4, extremely favorable - 5) and have 5 levels (Table 3 and Figure 1).

Table 3. Creation of non-Linear Typical Scales

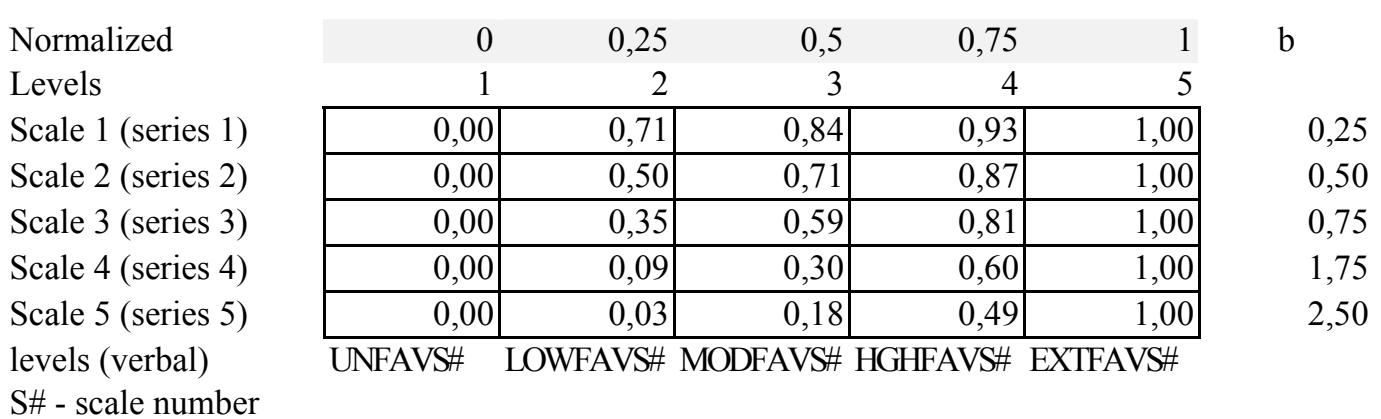

The general expression of the scales is $P=F(K)$, where $P$ is the degree of suitability of the corresponding sites according to a given criterion $-\mathrm{P} \in[0,1]$ :

$$
\mathrm{P}=\left(\left(\mathrm{K}_{\mathrm{i}}-\mathrm{K}_{\min }\right) /\left(\mathrm{K}_{\max }-\mathrm{K}_{\min }\right)\right)^{\mathrm{b}}
$$

where: $K_{i} \in[1,5]$ are the scale levels, and $b \in[0, \infty]$ is a coefficient of non-linearity depending on the importance of the corresponding criterion and forming the convex curve for $b \leq 1$ and a concave curve for b $>1$ (see Table 3 and Figure 3).

The results from the synthesis of model 1 - the ranking of models (see Figure 2) are used for grouping the criteria according to their importance. Five groups of criteria have been distinguished:

\begin{tabular}{|l|l|l|l|}
\hline Groups & Range of Priority & Criteria & Priority \\
\hline Group 1 & $\geq 0.200$ & H6 & 0.240 \\
\hline Group 2 & {$[0.120,0.200]$} & H1, E5 & $\{0.119,0.134\}$ \\
\hline Group 3 & {$[0.030,0.120]$} & F2,H2, E3,H5,F3 & $\{0.038, \ldots .0 .119\}$ \\
\hline Group 4 & {$[0.010,0.030]$} & F4, F1, G1, E4, H4, E2, F6, I1, G2, E1, H3 & $\{0.011, . ., 0.024\}$ \\
\hline Group 5 & $\leq 0.010$ & G3, I5, G4, I3, G6, I4, G5, F5, I2 & $\{0.002, \ldots, 0.008\}$ \\
\hline
\end{tabular}

A rating model is developed, the priorities of the single levels being determined in accordance to the above mentioned considerations, and the comparison of sites is made by the experts for each of the 28 criteria using the corresponding scale in the questionnaires. 
Figure 2. Ranking and classification of criteria

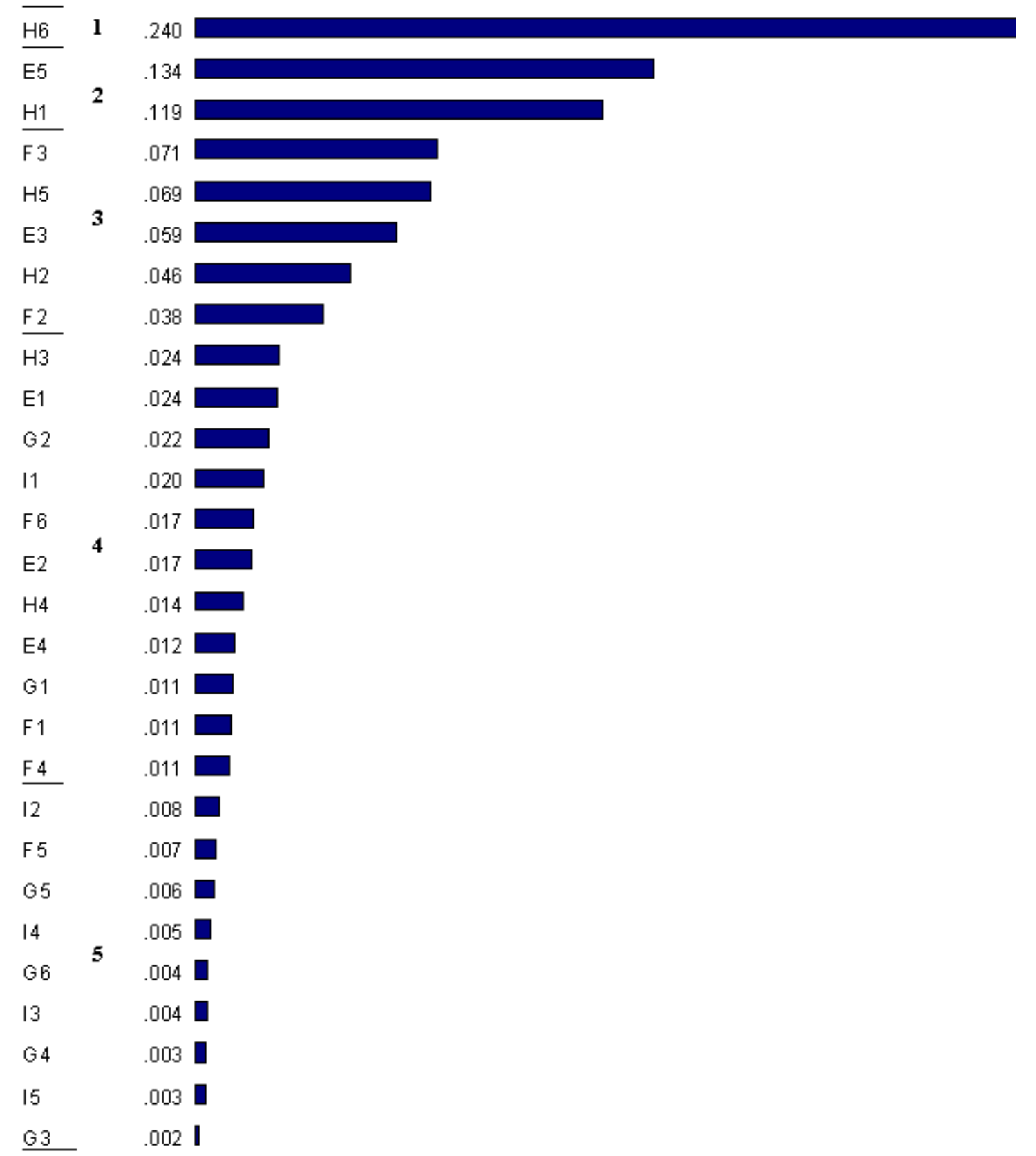

The results of the ranking are presented in Figure 4. As a rule, they are not so precise as the results obtained by pair comparisons for each area because of the uncertainty of some of the criteria. For this reason the results from the site ranking are used for each area by comparison in pairs.

A group of 6 more favorable sites from 2 areas - "Sakar" and "Dolnocredni Tereni" has been formed: 090S "Varbitza", 39AS "Garvanski Kamak", 400S "Sakartzi", 080S "Sumer", 390S "Stanchovo Pladniste" and 410S "Kushlovetz". Two areas "Severozapadna Bulgaria" and "Belene" are more unfavorable. 
Figure 3. Relationships between scale levels and their degree of preference

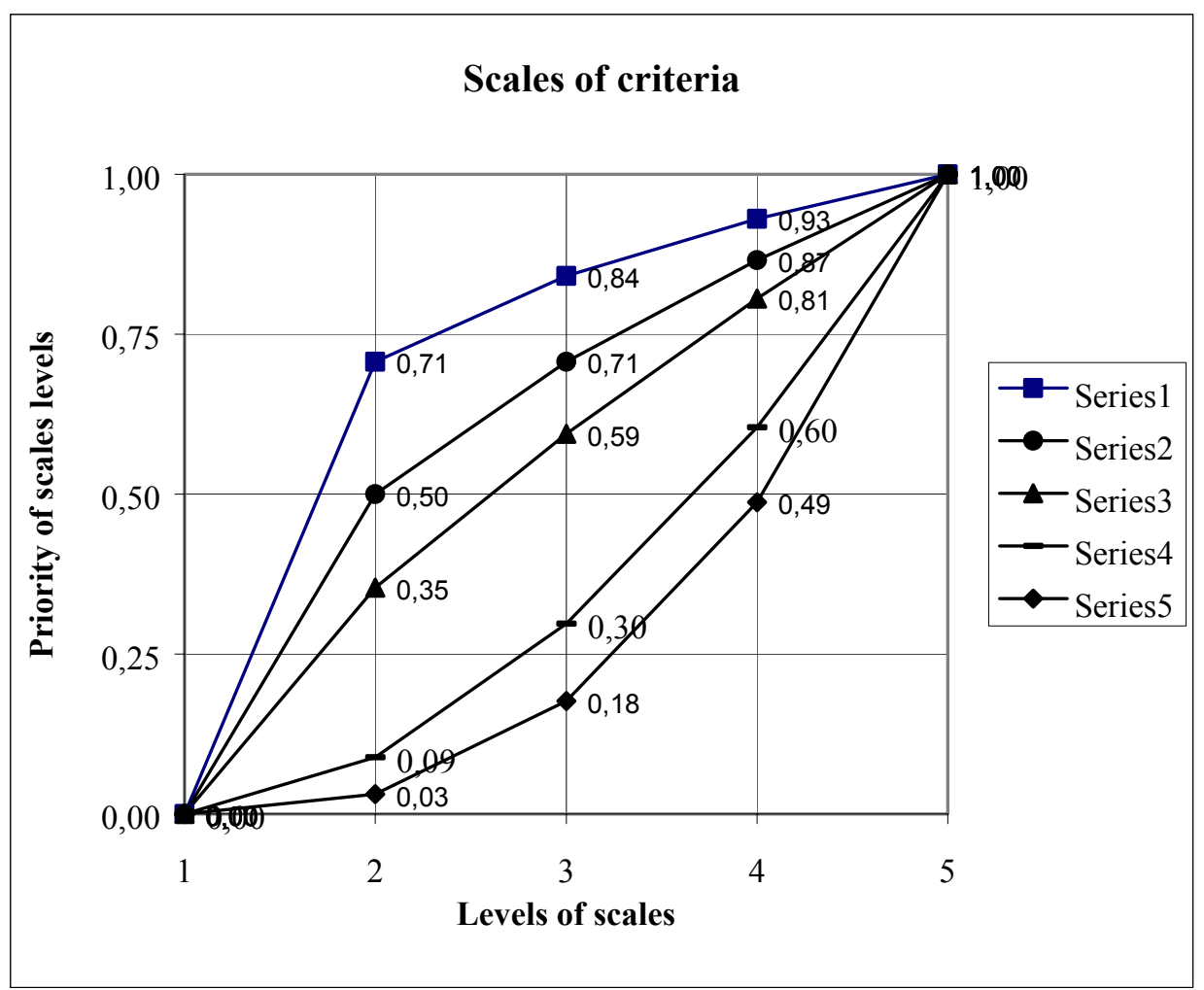

\section{References}

Radioactive Waste Management in Bulgaria (1997) PHARE Project.

Saati T. L. (1991) Multicriteria Decision Making: The Analytic Hierarchy Process, Planing, Priority Setting, Resource Allocation, RWS.

Vachev B., Badeva V and Tsvetanov P. (1983)," Methods for decision making under uncertainty for long term forecasting of large and complex economical systems development", Ikonomicheska misal, 3, 91101, (in bulgarien).

Vachev B.I. (1987) Reflection of uncertainty for investigation of national energy complex long term development, $\mathrm{PhD}$ thesis, Sofia,( in bulgarien).

Vachev B. I. and Evstatiev D. (1994) "Radioactive Wastes Management - AHP Application"

Proceedings of the Third Symposium on the Analytic Hierarchy Process, Washington, DC, 585-596.

Kozhoukharov D., Evstatiev D., Karastanev D., Todorov K. and Vachev B. (2000) "Investigations on Prospective Sites for the Construction of a National Radioactive Waste Repository", Project 102/98 Final Report, Institute of Geology, Sofia. 
Table 4. Sites ranking by each criterion

global local

\begin{tabular}{|c|c|c|c|c|c|c|}
\hline group & $\mathrm{H}$ & $\begin{array}{l}\text { Criter. } \\
\text { H6 }\end{array}$ & $\begin{array}{l}\text { Population radiological } \\
\text { impact }\end{array}$ & Importance: & 0,24 & 0,468 \\
\hline $\mathrm{N}$ & Site N. & Site N. & Area name & Site name & rating & \\
\hline 1 & 1 & $010 \mathrm{~S}$ & Severozapadna Bulgaria & Deleina & 1 & \\
\hline 2 & 4 & $040 \mathrm{~S}$ & Severozapadna Bulgaria & Dalgodeltzi & 1 & \\
\hline 3 & 8 & 080S & Dolnocredni tereni & Sumer & 4 & \\
\hline 4 & 9 & 090S & Dolnocredni tereni & Varbitza & 5 & \\
\hline 5 & 15 & $150 \mathrm{~S}$ & Dolnocredni tereni & Zlatar & 4 & \\
\hline 6 & 12 & $120 \mathrm{~S}$ & Belene & AEC-Belene & 2 & \\
\hline 7 & 13 & $130 \mathrm{~S}$ & Belene & Oresh & 3 & \\
\hline 8 & 23 & $230 \mathrm{~S}$ & Avren & Oreta & 3 & \\
\hline 9 & 24 & $240 \mathrm{~S}$ & Avren & Devisilovo & 3 & \\
\hline 10 & 25 & $250 \mathrm{~S}$ & Jalti chal & Vangelova chuka & 3 & \\
\hline 11 & 26 & $260 \mathrm{~S}$ & Jalti chal & Kurbanlaka & 3 & \\
\hline 12 & 27 & $270 \mathrm{~S}$ & Jalti chal & Kerezliiska reka & 3 & \\
\hline 13 & 28 & $280 \mathrm{~S}$ & Belorechka struktura & Sveta Elena & 3 & \\
\hline 14 & 29 & $290 \mathrm{~S}$ & Belorechka struktura & Chomakovia kladenec & 3 & \\
\hline 15 & 30 & $300 \mathrm{~S}$ & Belorechka struktura & Kodja guile & 3 & \\
\hline 16 & 31 & $310 \mathrm{~S}$ & Belorechka struktura & Pojarite & 3 & \\
\hline 17 & 32 & $320 \mathrm{~S}$ & Harmanliiski blok & Giklidja & 3 & \\
\hline 18 & 33 & $330 \mathrm{~S}$ & Harmanliiski blok & Huhla & 3 & \\
\hline 19 & 34 & $340 \mathrm{~S}$ & Harmanliiski blok & Ratiovitza & 3 & \\
\hline 20 & 35 & $350 \mathrm{~S}$ & Harmanliiski blok & Orlina & 3 & \\
\hline 21 & $35 \mathrm{a}$ & $35 \mathrm{AS}$ & Harmanliiski blok & Kumtarla & 3 & \\
\hline 22 & 36 & $360 \mathrm{~S}$ & Iugoiztochen Sakar & Aiazmoto & 3 & \\
\hline 23 & 37 & $370 \mathrm{~S}$ & Iugoiztochen Sakar & Bialata cheshma & 3 & \\
\hline 24 & 38 & $380 \mathrm{~S}$ & Iugoiztochen Sakar & Kachulka & 3 & \\
\hline 25 & 39 & $390 \mathrm{~S}$ & Sakar & Stanchovo pladniste & 4 & \\
\hline 26 & $39 \mathrm{a}$ & 39AS & Sakar & Garvanski kamak & 4 & \\
\hline 27 & 40 & $400 \mathrm{~S}$ & Sakar & Sakartzi & 4 & \\
\hline 28 & 41 & $410 \mathrm{~S}$ & Sakar & Kushlovetz & 4 & \\
\hline 29 & 42 & $420 \mathrm{~S}$ & Sakar & Iukpazar & 3 & \\
\hline 30 & $42 \mathrm{a}$ & $42 \mathrm{AS}$ & Sakar & Gospodinovi dabichki & 3 & \\
\hline
\end{tabular}


Figure 4. Sites ranking as a \% of site with maximal priority.

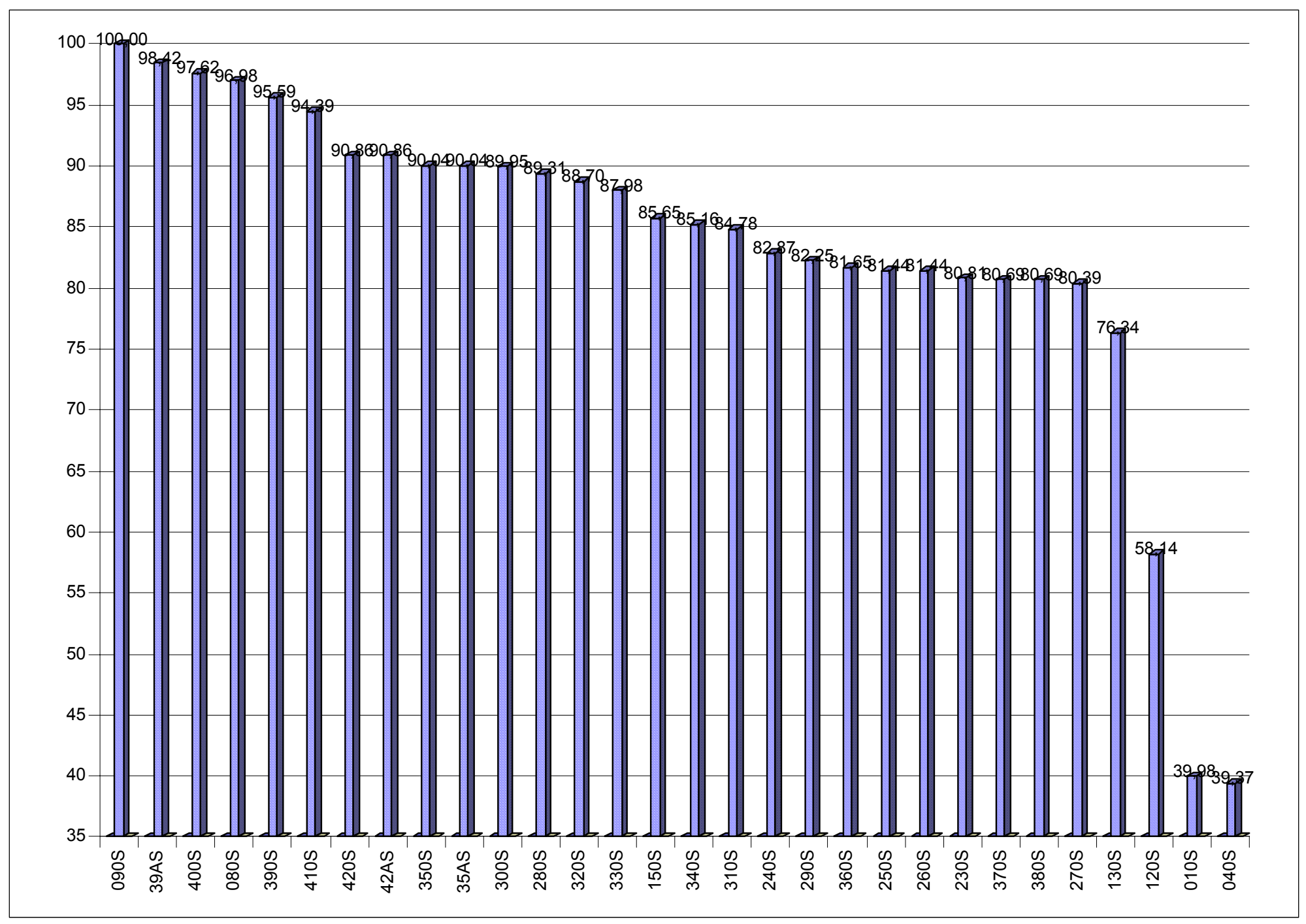

